\title{
A Study of Effects of Village Based Plant Clinic Service in Selected Regions of Ethiopia
}

June 2021

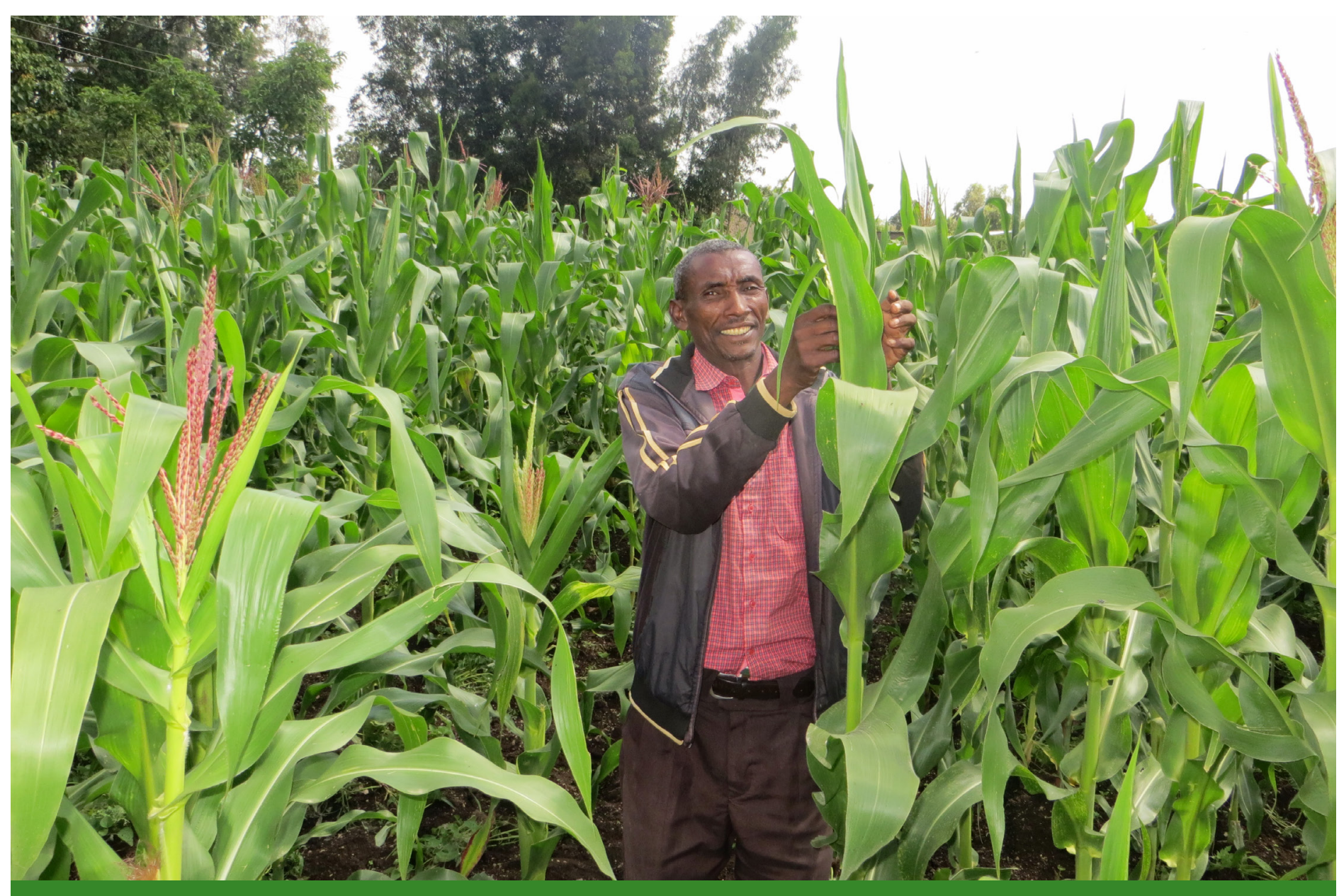

Negussie Efa Gurmessa

Mary Bundi

Frances Williams 


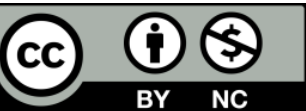

The copyright holder of this work is $\mathrm{CAB}$ International (trading as $\mathrm{CABI}$ ). It is made available under a Creative Commons Attribution-Non-commercial Licence (CC BY-NC). For further details please refer to http://creativecommons.org/license.

This study was implemented, and the CABI Working Paper prepared as part of the Plantwise programme. Plantwise is supported by contributions from the UK Foreign, Commonwealth and Development Office (FCDO), the Swiss Agency for Development and Cooperation (SDC), the Directorate General for International Cooperation (DGIS, Netherlands), the International Fund for Agricultural Development (IFAD), the Australian Centre for International Agricultural Research (ACIAR), and the Ministry of Agriculture and Rural Affairs of the People's Republic of China.

$\mathrm{CABI}$ is an international intergovernmental organization, and we gratefully acknowledge the core financial support from our member countries (and lead agencies) including the United Kingdom (Foreign, Commonwealth and Development Office), China (Chinese Ministry of Agriculture and Rural Affairs), Australia (Australian Centre for International Agricultural Research), Canada (Agriculture and Agri-Food Canada), the Netherlands (DirectorateGeneral for International Cooperation) and Switzerland (Swiss Agency for Development and Cooperation). See http://www.cabi.org/about-cabi/who-we-work-with/key-donors/ for full details.

This $C A B I$ Working Paper was internally peer-reviewed. It may be referred to as: Gurmessa, N., Bundi, M., Williams, F. (2021) A Study of Effects of Village-based Plant Clinic Service in Selected Regions of Ethiopia. CABI Working Paper 23, 18 pp. DOI: https://dx.doi.org/10.1079/CABICOMM-62-8157

Negussie Efa Gurmessa, CABI, PO Box 100913, Addis Ababa, Ethiopia

Email: e.negussie@cabi.org; ORCID: 0000-0002-3771-5275

Mary Bundi, CABI, Canary Bird, 673 Limuru Road, Muthaiga, PO Box 633-00621, Nairobi, Kenya

Email: m.bundi@cabi.org; ORCID: 0000-0002-6431-0273

Frances Williams, CABI, Canary Bird, 673 Limuru Road, Muthaiga, PO Box 633-00621, Nairobi, Kenya

Email: f.williams@cabi.org; ORCID: 0000-0002-6772-0753

Front cover photo: Negussie Efa, CABI (with the agreement of the farmer) 


\section{Table of Contents}

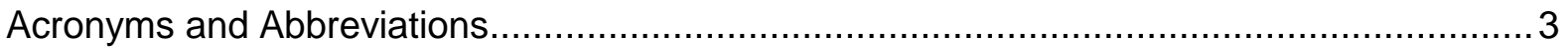

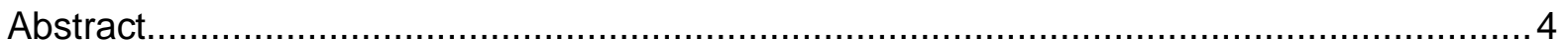

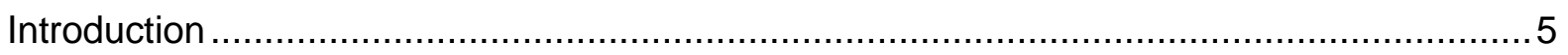

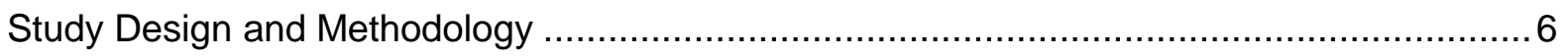

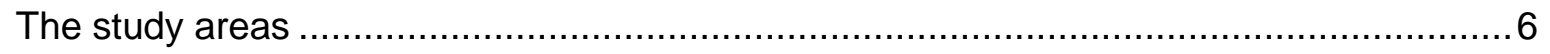

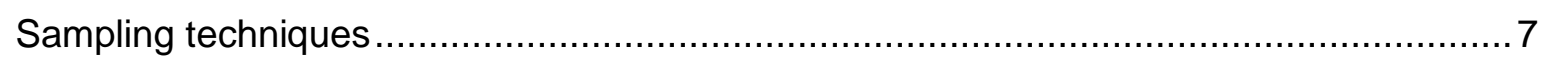

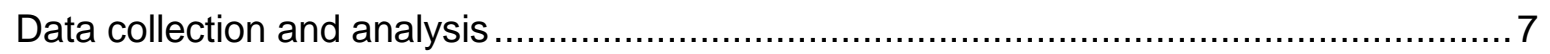

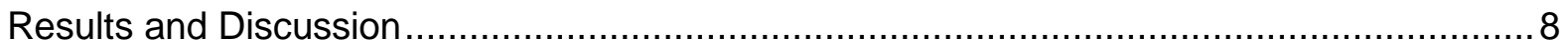

Farming-related characteristics of plant clinic users ............................................ 8

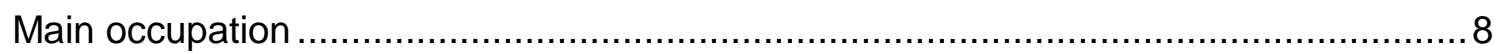

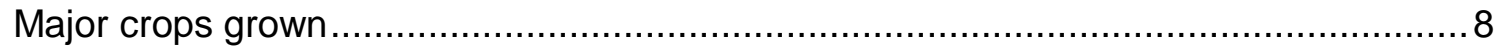

Crops brought to plant clinics by farmers ...................................................... 8

Type and use of recommendations given at plant clinics ....................................... 9

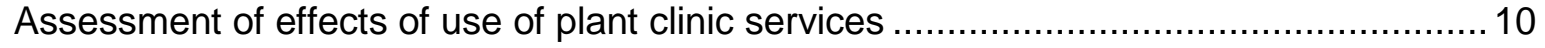

Change in farming area, fertilizer and improved seed use .................................. 10

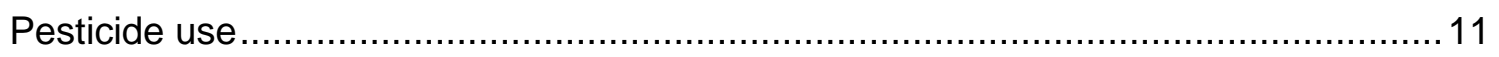

Improvements in use of PPE and disposal of empty pesticide containers.................. 12

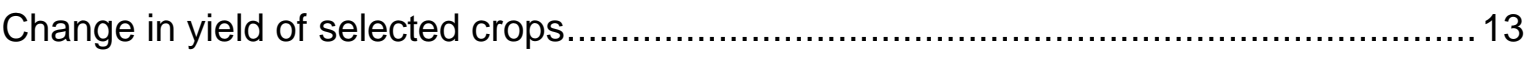

Change in income generated from the sale of selected crops .................................. 14

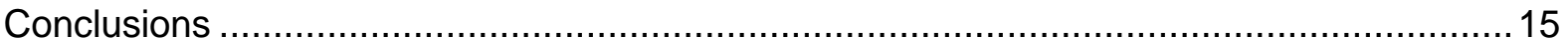

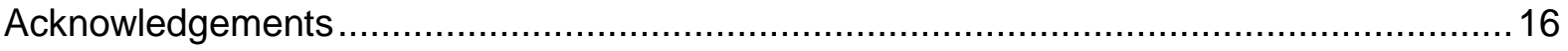

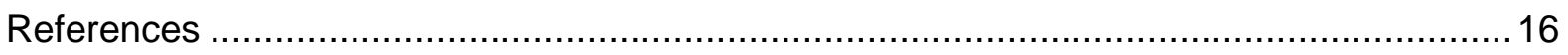

\section{Acronyms and Abbreviations}

FTC Farmers' training centre

IPM Integrated pest management

PPE Personal protective equipment 


\section{Abstract}

This study examined the effects of pest management advice given at village-based plant clinics in selected regions of Ethiopia on three key crops grown and brought to plant clinics in the study areas: maize, potato and tomato. The results showed that while there is reduction in use of pesticides among farmers, which can be taken as a positive outcome, there has been an increasing trend in the use of other inputs such as fertilizer and improved seed varieties. Farmers demonstrated better knowledge and practices regarding pesticide use following the plant clinic visit, especially with regards to use of personal protective equipment (PPE) and disposal of empty pesticide containers. They also spent less on pesticides as they started adopting non-chemical pest management options. Indicative results reveal a significant increase in maize, tomato and potato yields and farmers' income after visiting plant clinics, although this cannot be entirely attributed to plant clinics. The findings suggest that villagebased plant clinics enhance farmers' access to information on sustainable management of plant health problems resulting in increased farmer productivity and income. 


\section{Introduction}

Agriculture, characterized by smallholder farmers and subsistence farming, is the mainstay of the Ethiopian economy and a major source of livelihood for the majority of the population. However, efforts to raise production and productivity of the sector is faced with several challenges including crop pests and diseases. Damage caused by crop pests affects not only production and productivity, but also compromises product quality, marketability and ultimately the income of the farming community. It has been reported that in Ethiopia, estimated pre-and post-harvest losses due to pests range between 30\% and 50\% (Shiferaw et al., 2016). Pest damage at global level causes an estimated loss as high as $40 \%$ of annual crop production (Savary et al., 2019). Reducing crop losses due to pests and diseases, and increasing agricultural productivity is critical to improving smallholder farmers' livelihoods and enabling countries to meet the United Nations Sustainable Development Goals 1 and 2 (no poverty, zero hunger). However, in order to reduce crop losses, farmers need access to timely and relevant advice on crop health problem management (Tambo et al., 2020) through effective agricultural extension services.

Although Ethiopia is said to have a high concentration of frontline extension staff ${ }^{1}$ (Ragasa et al., 2013), as well as local structures such as farmers' training centres (FTCs), there are obvious gaps in the conventional extension system in terms of providing practical plant health advice to farmers (MoANR, 2016). Countries, including Mozambique, Malawi, India and many Latin American countries now focus on the provision of extension services to farmers through a pluralistic approach (Chowa et al., 2013; Gêmo et al., 2013; Singh et al., 2013; Klerkx et al 2016; Masangano et al., 2017) that involves both public and private sectors. Plantwise, through its community-based plant clinics offers an alternative approach to address some of the critical gaps in plant health advisory services and forms part of a pluralistic extension approach (Negussie et al., 2017). Plant clinics are primary plant health care services that operate in readily accessible places such as local markets, villages, cooperative centres or FTCs (Bentley et al., 2009; Negussie et al., 2017). In Ethiopia, plant clinics run on a weekly or fortnightly basis. Farmers take samples of their affected crops to trained extension officers (known as plant doctors) and receive diagnostic and advisory services on how to manage the problems. In Ethiopia, Plantwise builds the capacity of field-based government extension staff to run plant clinics and serve as plant doctors through innovative training on pest diagnosis and giving good advice to farmers. Thus, the Plantwise approach uses the existing organizational structures for synergy in improving advisory service delivery for improved plant health management (Danielsen et al., 2013; Negussie et al., 2017). The village-based plant clinics provide a service that is demand-driven by farmers, and provides information and advice on the key crop problems that the farmers face (Negussie et al., 2017). The advice given at plant clinics is guided by integrated pest management (IPM) principles, and focuses on the provision of safe, economic and practical recommendations (Danielsen et al., 2013).

In Ethiopia, community-based plant clinics were launched in late 2013 through the establishment of eight pilot clinics in the Oromia region. Further plant clinics were established in Tigray and Amhara regions in 2014, in the Southern Nations Nationalities and Peoples region in 2017 and Dire Dawa Administrative Council, Benshangul Gumz and Sidama regions in 2019. Additional plant clinics have been established in Oromia, Tigray and Amhara since 2014

\footnotetext{
${ }^{1}$ There are three agriculture development agents (for plant science, livestock and natural resources) in each rural kebele (village).
} 
as the programme expanded in response to government demand. There are currently about 200 community-based plant clinics operating across six regions of Ethiopia (CABI/MoA, 2019).

The government is keen to further expand plant clinic services as a means through which to effectively reach out to more farmers with pest management advisory services. However, while there have been a number of studies in other Plantwise countries that have examined the effect of plant clinics on farmer knowledge and practices, and crop yield and income, no such studies have been carried out in Ethiopia. Thus, this study examined the effects of implementation of recommendations given to farmers at plant clinics, in terms of crops produced, farmers' knowledge and practices, land area under selected crops, use of farming inputs, use of personal protective equipment (PPE), yield and income from the study crops.

The results in this study complement the detailed findings in Gurmessa and Bundi (2021) from the same field study, on the plant health problems presented at plant clinics, pesticide usage (type, amount, spraying frequency, etc.), factors affecting the use of plant clinic advice, and adoption levels of plant clinic advice.

\section{Study Design and Methodology}

\section{The study areas}

This study was carried out in December 2018 and January 2019 in three districts (Shashemene, Fogera and Seharti Samre) selected from the three major regions (Amhara, Oromia and Tigray) implementing Plantwise in Ethiopia (Figure 1). Additional location details are provided in Gurmessa and Bundi (2021). Fogera is one of the districts in South Gonder zone of Amhara regional state. The district is known for its high agricultural potential and suitability for rice production. Teff, maize, rice, wheat, finger millet, barley, lentil and horse bean are the major food crops grown in the district. The major cash crops include horticultural crops such as onion, tomato, garlic and potato. The second study district (Shashemene) is located in West Arsi zone of Oromia regional state. The district is one of the highly productive areas with various crops grown in the area. The major food crops include maize, wheat, teff, potato, barley and haricot bean. Potato, tomato, onion, pepper and coffee are among the major cash crops grown in Shashemene. The third study district, Seharti Samre, is located in Central Tigray regional state. The major food crops grown in the area include maize, wheat, teff, sorghum, horse bean and barley, while the major cash crops include tomato, garlic, onion, potato, cabbage and beans. 


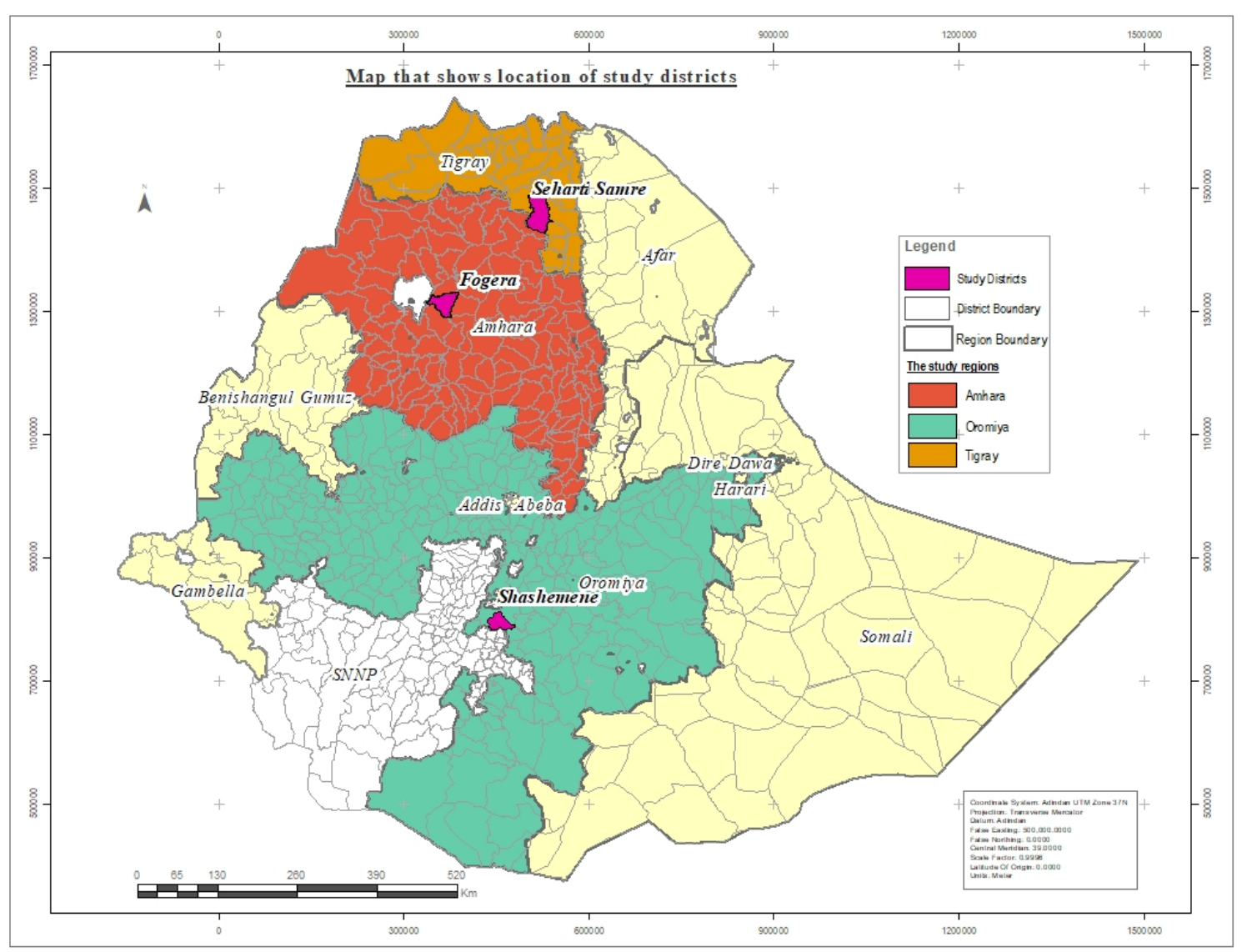

Figure 1. This study was carried out in three districts (Shashemene, Fogera and Seharti Samre) selected from the three major regions (Amhara, Oromia and Tigray) implementing Plantwise in Ethiopia. Source: adapted from Ethio-GIS, 2001, E.C.

\section{Sampling techniques}

All the three major regions where Plantwise was introduced in 2013 and 2014 were purposively selected for the study. As stated in Gurmessa and Bundi (2021) this was followed by purposive selection of three districts, one district from each region. Out of the two plant clinics in each district, one plant clinic site was purposively sampled for Shashemene and Seharti Samre districts (Awasho Danku and Teshi clinics, respectively), while both clinics (Woreta zuria and Koar Michael) were included in the study in Fogera district. Teshi plant clinic was launched in 2014 and runs weekly at the FTC on a market day, which is close to the market centre and is operated by a female plant doctor. The originally trained plant doctor still runs this clinic, while the other three study clinics experienced a change of plant doctors. Awasho Danku clinic was launched in late 2013 and runs weekly on a market day at the village centre. Koar Michael and Woreta Zuria clinics were launched in late 2014 and operate weekly at kebele, cooperative centres where farmers frequently congregate. Systematic random sampling technique was used to select 70 farmers from each district, using plant clinic record forms, bringing the total to 210 plant-clinic-user farmers.

\section{Data collection and analysis}

Structured questionnaires were pre-tested and used to collect data from the randomly selected farmers. The questionnaire was designed to allow capturing of data on both experiences and 
practices of farmers before visiting plant clinics (recall information) and after visiting plant clinics. The questionnaires were administered by trained zonal/district experts through faceto-face interviews with farmers. Regional experts served as supervisors of the data collection process. Although the questionnaires were prepared in English, interviewers administered the questionnaires to farmers in their respective local languages. To enable the assessment of changes related to adoption of plant clinic advice on production and income, the survey considered three key crops - maize, tomato and potato.

SPSS 20 was used to analyse the data. Descriptive statistics such as frequency tables, means and percentage distributions were generated. In addition, $t$-tests were used to make comparisons of means of variables such as farm land area, yield and income. Information from secondary sources were summarized, synthesized and used to complement the primary data.

\section{Results and Discussion}

\section{Farming-related characteristics of plant clinic users}

\section{Main occupation}

The study shows that users of plant clinics are smallholder farmers with an average land holding of less than 1 ha. The findings reveal that the vast majority of plant clinic users primarily earn their livelihood from farming (91.5\%), while only $8.5 \%$ indicated a combination of farming and wage/casual labour, trade/business and salaried employment as their main source of income.

\section{Major crops grown}

Diverse crops are grown in the study districts with variations based on agro-ecological conditions. As indicated in Table 1, maize, wheat, rice, sorghum/millet, peas and chickpeas are the major food crops grown in the study areas, in that order. The major cash crops grown in the study areas include tomato, potato, onion, garlic and haricot bean. These data confirm the decision taken to focus on maize, tomato and potato as the study crops.

Table 1. Major crops grown by respondent farmers and the reason for growing them

\begin{tabular}{|lc|}
\hline Food security (in order of importance) & Cash (household income) \\
\hline Maize & Tomato \\
\hline Wheat & Potato \\
\hline Rice & Onion \\
\hline Sorghum and millet & Garlic \\
\hline Peas, chickpea & Haricot bean \\
\hline
\end{tabular}

\section{Crops brought to plant clinics by farmers}

As presented in Table 2, the main crops brought to the sampled plant clinics include maize, wheat, tomato, onion, teff and others in that order. These varied from district to district based on agro-ecology and farming system. The records of crops taken to plant clinics suggests that farmers seem to care more about major food crops (cereals) and cash crops than other crops 
they grow. Although we recognize that farmers are rational and make decisions that serve their best interest, it would be important to educate and encourage them to bring problems on any of the multiple crops they grow, including minor crops grown on backyard gardens, and those managed by female farmers.

Table 2. Crops brought to the surveyed plant clinics

\begin{tabular}{|lcc|}
\hline Crops brought to clinics & $\begin{array}{c}\text { Number of queries } \\
\text { brought }\end{array}$ & $\begin{array}{c}\text { Percentage of } \\
\text { queries brought }\end{array}$ \\
\hline Maize & 30 & $15.0 \%$ \\
\hline Wheat & 23 & $11.5 \%$ \\
\hline Teff & 15 & $7.5 \%$ \\
\hline Onion & 14 & $7.0 \%$ \\
\hline Tomato & 8 & $4.0 \%$ \\
\hline Maize and tomato & 17 & $8.5 \%$ \\
\hline Maize and wheat & 14 & $7.0 \%$ \\
\hline Maize, wheat and teff & 9 & $4.5 \%$ \\
\hline Onion and tomato & 8 & $4.0 \%$ \\
\hline Wheat and potato & 7 & $3.5 \%$ \\
\hline Maize and onion & 7 & $3.5 \%$ \\
\hline Teff and garlic & 5 & $2.5 \%$ \\
\hline $\begin{array}{l}\text { One or two of the above crops with } \\
\text { other crops }\end{array}$ & 43 & $21.5 \%$ \\
\hline Total & $\mathbf{2 0 0}$ & $\mathbf{1 0 0 \%}$ \\
\hline
\end{tabular}

\section{Type and use of recommendations given at plant clinics}

Upon visiting plant clinics with samples of their sick plants, the majority of farmers (69\%) were advised to use a combination of monitoring, cultural practices and pesticides. An estimated $15 \%$ of the respondents were advised to use monitoring/scouting and cultural practices, while $11 \%$ were advised to use pesticides only (Gurmessa and Bundi, 2021). This suggests that plant doctors were applying their acquired skills from the Plantwise training by largely following IPM principles in giving recommendations. Only $5 \%$ of the recommendations were for farmers to plant resistant varieties, together with cultural practice or pesticides. Further investigations might be needed to find out whether this is due to lack or shortage of resistant varieties, or lack of awareness among plant doctors, which may need intervention.

Overall, $98 \%$ of the plant clinic visitors implemented the recommendations given at plant clinics to a varying degree, whereby $64 \%$ and $34 \%$, respectively, fully or partially applied the recommendations given by plant doctors (Gurmessa and Bundi, 2021). Such high adoption rates should not be surprising as plant clinics provide a demand-driven service to farmers with serious plant health problems. Among those who applied the recommendations, the larger proportion (46\%) used both cultural practices and pesticides, while $31 \%$ and $18 \%$ applied only pesticides or cultural practices, respectively. Although only $11 \%$ of the recommendations given by plant doctors were pesticides only, more farmers (31\%) reported actually using pesticides only (Gurmessa and Bundi, 2021). This shows that some farmers unpacked the recommendations and applied pesticides, contrary to the plant doctors' recommendations, 
which calls for deliberate efforts to educate and persuade farmers to make wider use of cultural practices and other non-chemical pest management options.

\section{Assessment of effects of use of plant clinic services}

\section{Change in farming area, fertilizer and improved seed use}

As shown in Table 3, the area of land used by respondent farmers to cultivate the selected crops (maize, potato and tomato) increased after the launch of plant clinics in the area. Although they appear minimal, the changes were found to be statistically significant. The reason for this is unclear, but it may be useful to investigate further, whether the changes are due to an increased total area of land under cultivation (which could be more likely through renting more plots), or whether the area of land under other crops has decreased as more maize, potato and tomato have been planted. (Note, based on knowledge of the study areas, it is unlikely that extra land has been cleared to increase the area under cultivation.) It would also be important to closely examine if farmers were motivated by the increased productivity of the target crops as a result of the improved pest management services provided to them by plant doctors and decided to reallocate land to the more profitable crops.

Table 3. Change in area under maize, tomato and potato after visiting plant clinics

\begin{tabular}{|lcccc|}
\hline Type of crop & $\begin{array}{c}\text { Before launch } \\
\text { of plant clinics } \\
\text { (ha) }\end{array}$ & $\begin{array}{c}\text { After launch of } \\
\text { plant clinics (ha) }\end{array}$ & t-value & $\boldsymbol{P}^{\text {value }}$ \\
\hline Maize $(\mathrm{N}=140)$ & 0.29 & 0.35 & 3.675 & 0.001 \\
\hline Tomato $(\mathrm{N}=59)$ & 0.17 & 0.26 & 3.689 & 0.001 \\
\hline Potato $(\mathrm{N}=45)$ & 0.29 & 0.37 & 2.456 & 0.018 \\
\hline
\end{tabular}

* $p$-value shows significance at $<0.01$ level

As regards the change in use of farm inputs, we found a statistically significant increase in the use of fertilizer for all the three crops after visiting plant clinics (Table 4). This could suggest that plant doctors were encouraging farmers to use the recommended fertilizer rates (instead of below optimal rates) so as to enhance vigour and resistance of their crops to pests/diseases. Evidence shows that use of chemical fertilizers among smallholder farmers in Ethiopia is low compared with their counterparts in other east African countries (IFDC, 2015). Thus, findings of the current study suggest that plant clinics can play an important role in improving this situation.

However, regarding use of seeds of improved varieties we found a significant change only for maize and potato (Table 5). Such changes in the use of improved varieties for the two crops can be taken as a positive change as use of improved and/or resistant varieties is one of the economically and environmentally sound pest management options. However, lack of significant change for tomato may need further investigation to find out whether it is due to lack of seeds of improved tomato varieties or related to costs or local unavailability, or farmer preference for local varieties. 
Table 4. Change in use of fertilizer for the three crops after visiting plant clinics

\begin{tabular}{|lcccc|}
\hline $\begin{array}{l}\text { Fertilizer on } \\
\text { selected crop }\end{array}$ & $\begin{array}{l}\text { Before launch of } \\
\text { plant clinics } \mathbf{( k g )}\end{array}$ & $\begin{array}{c}\text { After launch of } \\
\text { plant clinics } \mathbf{( k g )}\end{array}$ & $\boldsymbol{t}$-value & $\boldsymbol{P}$ value* \\
\hline Maize $(\mathrm{N}=125)$ & 48 & 65 & 5.590 & 0.001 \\
\hline Tomato $(\mathrm{N}=53)$ & 36 & 55 & 4.315 & 0.001 \\
\hline Potato $(\mathrm{N}=43)$ & 93 & 140 & 3.258 & 0.002 \\
\hline * p-value shows significance at $<0.01$ level & & &
\end{tabular}

Table 5. Change in use of improved variety seeds after visiting plant clinics

\begin{tabular}{|lcccc|}
\hline Crops & $\begin{array}{c}\text { Before launch of } \\
\text { plant clinics } \mathbf{( k g )}\end{array}$ & $\begin{array}{c}\text { After launch of } \\
\text { plant clinics } \mathbf{( k g )}\end{array}$ & $\boldsymbol{t}$-value & $\boldsymbol{P}$ value \\
\hline Maize $(\mathrm{N}=133)$ & 9 & 11.50 & 3.147 & 0.002 \\
\hline Tomato $(\mathrm{N}=57)$ & 0.65 & 0.70 & 0.722 & 0.473 \\
\hline Potato $(\mathrm{N}=43)$ & 394 & 573 & 2.504 & 0.016 \\
\hline
\end{tabular}

\section{Pesticide use}

As shown in Table 6, after visiting plant clinics and receiving advisory services, farmers appeared to display better knowledge and practices regarding proper use of pesticides. For instance, over one-third (35\%) and close to two-thirds of the respondent farmers (61\%) felt that they have high or moderate knowledge of proper use of pesticides following a plant clinic visit, as opposed to only $2.5 \%$ and $28 \%$, respectively, before the launch of plant clinics in the areas. This could be largely attributed to the awareness raising and education activities carried out by plant doctors.

Table 6. Perceived knowledge on proper use of pesticides

\begin{tabular}{|lcc|}
\hline $\begin{array}{l}\text { Level of } \\
\text { knowledge }\end{array}$ & $\begin{array}{l}\text { Before visiting plant clinics } \\
\text { (number and \% of farmers) }\end{array}$ & $\begin{array}{c}\text { After visiting plant clinics } \\
\text { (number and \% of farmers) }\end{array}$ \\
\hline High & $5(2.5 \%)$ & $73(35 \%)$ \\
\hline Moderate & $58(28 \%)$ & $126(61 \%)$ \\
\hline Poor & $144(69.5 \%)$ & $9(4 \%)$ \\
\hline Total & $207(100 \%)$ & $208(100 \%)$ \\
\hline
\end{tabular}

The increased knowledge about proper pesticide use is reflected in a reduction in the total use of pesticides annually among the sampled plant clinic users (Gurmessa and Bundi, 2021), as well as, decreased expenditure on pesticides following their plant clinic visit (Table 7). The $t$ test result shows a significant reduction in the amount of cash the sampled clinic users spent annually on pesticides for all the crops they grow. On average, farmers annually spent 2,348.65 Birr (67 USD) on pesticides for their entire farming enterprise before visiting plant clinics as compared with 1,899.78 Birr (54 USD) after visiting plant clinics. This could be related to the awareness created through plant clinics and the mix of alternative management options (including non-chemical options) provided at plant clinics. This attribution could be justified by the fact that a trend of increasing quantities of pesticide use by farmers was recorded in other parts of the country (as reported by Negatu et al., 2016), where villagebased plant clinics are not operating. 
Table 7. Amount of money spent on pesticides before and after visiting plant clinics

\begin{tabular}{|lccc|}
\hline Period (before/after) & $\begin{array}{c}\text { Number of } \\
\text { Respondents }\end{array}$ & $\begin{array}{c}\text { Cash spent } \\
\text { annually (Birr) }\end{array}$ & Standard Deviation \\
\hline Before visiting plant clinics & 192 & 2348.65 & 2863.812 \\
\hline After visiting plant clinics & 192 & 1899.78 & 2052.106 \\
\hline
\end{tabular}

$t$-value $=2.79 ;$ degrees of freedom $=191 ; p$-value $=0.006$ (significant at $99 \%)$

\section{Improvements in use of PPE and disposal of empty pesticide containers}

Use of PPE has shown some improvement in the study areas in recent years, which could be at least partly attributed to plant clinic services. Overall, $37 \%$ of the respondent farmers reported using some sort of PPE at present as compared with only $11 \%$, before visiting plant clinics (Table 8). Out of the 23 farmers who reported using PPE before visiting plant clinics, 19 farmers (83\%) indicated using boots only, while four respondents used overalls, mask or gloves. After visiting plant clinics, about 50 respondents (out of 76 farmers) reported using boots alone, or together with other PPE, while 24 farmers reported using two or three combinations of PPE, such as overalls, mask, gloves or hats. Given the low level of use of PPE in the country, this improvement can be taken as a commendable change.

Table 8. Use of personal protective equipment (PPE)

\begin{tabular}{|lcc|}
\hline $\begin{array}{l}\text { Used protective } \\
\text { clothes during } \\
\text { spraying }\end{array}$ & $\begin{array}{c}\text { Before visiting plant } \\
\text { clinics (number of } \\
\text { farmers (\%)) }\end{array}$ & $\begin{array}{c}\text { After visiting plant clinics } \\
\text { (number of farmers (\%)) }\end{array}$ \\
\hline Yes & $23(11 \%)$ & $76(36.5 \%)$ \\
\hline No & $182(89 \%)$ & $132(63.5 \%)$ \\
\hline
\end{tabular}

As indicated in Table 9, following a plant clinic visit there has been improvement in the way farmers dispose of empty pesticide containers. Previously re-use of empty pesticide containers for holding household consumable items was a common practice among farmers. At present (after visiting plant clinics), only 13\% reported cleaning and reusing as storage containers for consumables, as opposed to $50 \%$ before visiting plant clinics. However, a considerable proportion (40\%) still dispose of empty pesticide containers by throwing them away from their farm land which is not an acceptable practice and needs further attention.

Table 9. How respondents dispose of empty pesticide containers

\begin{tabular}{|lcc|}
\hline Ways of disposal & $\begin{array}{c}\text { Before visiting plant } \\
\text { clinics } \\
\text { (number (\%)) }\end{array}$ & $\begin{array}{c}\text { After visiting plant } \\
\text { clinics } \\
\text { (number (\%)) }\end{array}$ \\
\hline $\begin{array}{l}\text { Burning/burying (away from water } \\
\text { source) }\end{array}$ & $16(8 \%)$ & $98(47 \%)$ \\
\hline Threw them away & $83(42 \%)$ & $83(40 \%)$ \\
\hline $\begin{array}{l}\text { Cleaned and used as storage } \\
\text { containers }\end{array}$ & $98(50 \%)$ & $26(13 \%)$ \\
\hline
\end{tabular}




\section{Change in yield of selected crops}

We tried to examine the effects of the plant clinic service in increasing production and income of farmers. However, some farmers were hesitant to give data on their yield and the income obtained from the sale of the three crops selected for this study. Moreover, some of the selected crops are predominantly grown only in some of the study woredas. For instance, among the three study districts, potato predominantly grows in Shashemene woreda, hence lower respondent numbers in the following analyses.

The paired $t$-test result shows that there was a significant $(t=11.25 ; P=0.001)$ increase in the production of maize after receiving clinic advice. On average, respondent farmers reported annually producing 1.28 tonnes of maize per household before the launch of plant clinics as compared with 1.99 tonnes at the time of this survey (after receiving advice from the plant clinic service) (Table 10), a 56\% increase. One of the limitations of the current study design is that the data were obtained for total yield increase per season for a particular household and crop, and not production per unit area. Thus there might be a need for a further study that examines an increase in yield per unit area to offset the effects due to an increase in land under cultivation.

The result also reveals a significant increment in the yields of tomato after visiting and receiving advice from the plant clinic service. For instance, the mean annual production of tomato rose from 6.2 tonnes per household before the launch of plant clinics to 9.95 tonnes after receiving plant clinic advice, a $60.5 \%$ increase. As shown in Table 10, the difference is also statistically significant $(t=4.53 ; P=0.001)$.

Table 10. Production of the three crops before and after visiting plant clinics

\begin{tabular}{|c|c|c|c|c|}
\hline Time/period & $\begin{array}{l}\text { Mean yield (tonnes) } \\
\text { Maize }(\mathrm{N}=140)\end{array}$ & $t$-value & $\begin{array}{l}\text { Degrees of } \\
\text { freedom }(\mathrm{df})\end{array}$ & $\begin{array}{c}\text { Standard } \\
\text { Deviation (SD) }\end{array}$ \\
\hline $\begin{array}{l}\text { Before visiting } \\
\text { clinics }\end{array}$ & 1.28 & 11.25 & 139 & 1.050 \\
\hline \multirow[t]{2}{*}{$\begin{array}{l}\text { After visiting } \\
\text { clinics }\end{array}$} & $1.99^{\star \star \star}$ & & & 1.313 \\
\hline & Tomato (N = 55) & $t$-value & $\mathrm{df}$ & SD \\
\hline $\begin{array}{l}\text { Before visiting } \\
\text { clinics }\end{array}$ & 6.2 & 4.53 & 54 & 7.43 \\
\hline \multirow{2}{*}{$\begin{array}{l}\text { After visiting } \\
\text { clinics }\end{array}$} & $9.95^{\star \star \star}$ & & & 7.08 \\
\hline & Potato $(\mathrm{N}=40)$ & $t$-value & $\mathrm{df}$ & SD \\
\hline $\begin{array}{l}\text { Before visiting } \\
\text { clinics }\end{array}$ & 7.5 & 2.54 & 39 & 10.81 \\
\hline $\begin{array}{l}\text { After visiting } \\
\text { clinics }\end{array}$ & $11^{\star \star \star}$ & & & 11.11 \\
\hline
\end{tabular}


Similarly, the mean annual production of potato per farmer increased from 7.50 tonnes to 11 tonnes per household ( $47 \%$ increase) after using plant clinic services (Table 10). Nevertheless, although there are indications that access to and use of plant clinic services has played its part in this regard, it would not be realistic to attribute the entire change (increment) in production to plant clinic services. Other interventions and the modest increment in land area under production could have partly contributed to the observed changes. This calls for further work with a more rigorous study design that enables control for the other intervention effects and an increase in land area.

\section{Change in income generated from the sale of selected crops}

Likewise, the findings from some of the farmers who provided data on their income shows a significant increment in the income generated from the sale of the three crops. In this regard, the paired $t$-test result shows that there was a significant $(t=10.27 ; P=0.001)$ increase in the income generated from sale of maize after receiving plant clinic services (Table 11). On average, farmers reported annually earning 3,534 Birr (101 USD) from sale of maize before the launch of plant clinics in the study areas as compared to 9,013 Birr (258 USD) at present (after receiving plant clinic advice), a 155\% increase. These findings are supported by the findings of a study conducted in other African countries (Tambo et al., 2020) which reported that the positive technology adoption effect of plant clinics significantly translates into higher yield and income gains of $28 \%$ and $23 \%$, respectively. However, some of the increments could be partly attributed to the changes in prices of agricultural commodities, which have shown substantial increment in recent years. A control group of farmers who had not visited plant clinics would have helped to ascertain whether some of the increase in income was purely due to commodity prices increases: however, this was not possible in this study design.

Table 11. Income from sale of the three crops before and after visiting plant clinics

\begin{tabular}{|c|c|c|c|c|}
\hline Time/period & $\begin{array}{c}\text { Mean income (Birr) } \\
\text { Maize }(\mathrm{N}=113)\end{array}$ & $t$-value & $\begin{array}{l}\text { Degrees of } \\
\text { freedom (df) }\end{array}$ & $\begin{array}{c}\text { Standard } \\
\text { Deviation (SD) }\end{array}$ \\
\hline $\begin{array}{l}\text { Before visiting } \\
\text { clinics }\end{array}$ & 3534 & 10.27 & 112 & 3696.93 \\
\hline \multirow{2}{*}{$\begin{array}{l}\text { After visiting } \\
\text { clinics }\end{array}$} & $9013^{\star \star \star}$ & & & 7508.48 \\
\hline & Tomato $(\mathrm{N}=43)$ & $t$-value & $\mathrm{df}$ & SD \\
\hline $\begin{array}{l}\text { Before visiting } \\
\text { clinics }\end{array}$ & 4,512 & 4.19 & 42 & 6883.45 \\
\hline \multirow{2}{*}{$\begin{array}{l}\text { After visiting } \\
\text { clinics }\end{array}$} & $10,389 * \star \star$ & & & 6883.91 \\
\hline & Potato (N = 36) & $t$-value & df & SD \\
\hline $\begin{array}{l}\text { Before visiting } \\
\text { clinics }\end{array}$ & 15,843 & 4.879 & 35 & 14872.79 \\
\hline $\begin{array}{l}\text { After visiting } \\
\text { clinics }\end{array}$ & $38,500^{\star * \star}$ & & & 39451.02 \\
\hline
\end{tabular}


We similarly noted a significant increment $(t=4.19 ; P=0.001)$ in the income farmers derived from the sale of tomato crop following use of plant clinic services. As presented in Table 11, farmers reported on average obtaining 4,512 Birr (115 USD) during the season before their plant clinic visit, while they reported generating 10,389 Birr (265 USD) during the current survey season (after receiving plant clinic advice), a 130\% increase.

The same trend was observed with regard to the income generated from potato production. As presented in Table 11, the income generated from sale of potato grew by more than twofold after receiving plant clinic services from 15,843 Birr (400 USD) to 38,500 Birr (970 USD), a $143 \%$ increase. Such massive increment could be at least partly attributed to the support provided by plant clinics which help avoid or minimize losses caused by crop pests. However, it is important to note that there have been massive increments in the prices of agricultural commodities in Ethiopia in recent years, which is related to the high inflation rates.

\section{Conclusions}

This study examined the effects of plant clinic advice in Ethiopia, complementing the discussion on use of plant clinic advice found in Gurmessa and Bundi (2021). Various crops and pest problems were brought to plant clinics, and these varied depending on agro-ecology, farming system and the importance attached to the different crops. Major food and cash crops appear to be given priority by farmers, with the majority of plant clinic queries related to the major crops grown in the study areas, though plant clinics are open to all crops and all plant health problems.

Key findings show that after visiting plant clinics, farmers used more fertilizer up to recommended levels, more improved varieties of maize and potato seed, and annually spent less on pesticides on their farms. These changes in practices suggest that farmers are increasingly following good agricultural practices. As a result of these changes in agricultural practices and an increase in area under cultivation, indicative findings show a significant increase in the production of the three crops. While we were not able to state conclusively that these changes are entirely a result of using plant clinic services, the findings suggest that the advice received has resulted in some yield increase, which can be particularly due to increased use of fertilizer and IPM approaches such as improved seed varieties and nonchemical pest management options. These findings are in line with other studies that have examined the effect of plant clinic services on farmer yields in other countries (Bett et al., 2018; Ghosh et al., 2019; Silvestri et al., 2019; Tambo et al., 2020). These studies demonstrate that if farmers adopt the recommendations provided at plant clinics they obtain greater yields than farmers growing the same crops who did not visit plant clinics.

When considering the increase in income that farmers in Ethiopia obtained after visiting plant clinics, this can again be partly attributed to adoption of plant clinic recommendations (Bett et al., 2018; Ghosh et al., 2019; Silvestri et al., 2019; Tambo et al., 2020), through the reduction of cost of pesticides used as well as the higher yield. It is possible that a higher value for the crop is also obtained if the crop is of better quality, though this should be further investigated to determine if this is the case. Some of the gains could also be attributed to other interventions and the general rise in the prices of agricultural commodities in recent years.

Finally, farmers who had visited plant clinics also used more PPE, and are more careful in their disposal of empty pesticide containers. These findings are in agreement with those of 
other studies (Musebe et al., 2018; Tambo et al., 2021), and in the long term should lead to a reduction in adverse health effects of chemical pesticides for farmers.

Overall, findings suggest that plant clinics provide an effective complementary approach to pest management advisory service provision, which is in line with the concepts and practices of pluralistic agricultural extension service delivery of the current era.

\section{Acknowledgements}

We would like to acknowledge the support provided by Plantwise Partners in Ethiopia; the Ministry of Agriculture (MoA), Plantwise national and regional coordinators, Plantwise national data manager and plant doctors in Shashemene, Seharti Samre and Fogera districts for their role in supporting this work during the farmer surveys. We would also like to thank the enumerators that took part in administering the survey questionnaires. In addition, we would also thank Mr Tesfaye Taye, MoA, for his support in creating the map for the study areas (Figure 1).

\section{References}

Bentley, J.W., Boa, E., Danielsen, S., Franco, P., Antezana, O., et al. (2009) Plant health clinics in Bolivia 2000-2009: operations and preliminary results. Food Security 1(3), 371386. https://doi.org/10.1007/s12571-009-0033-z

Bett, E., Mugwe, J., Nyalugwe, N., Haraman, E., Williams, F., et al. (2018) Impact of plant clinics on disease and pest management, tomato productivity and profitability in Malawi. CABI Working Paper 11, 30 pp. https://dx.doi.org/10.1079/CABICOMM-25-8089

CABI/MoA (Ministry of Agriculture) (2019) Plantwise Ethiopia Annual Report, 2019. CAB International and MoA, Addis Ababa, Ethiopia.

Chowa, C., Garforth, C. and Cardey, S. (2013) Farmer experience of pluralistic agricultural extension, Malawi. The Journal of Agricultural Education and Extension 19(2), 147-166. https://dx.doi.org/10.1080/1389224X.2012.735620

Danielsen, S., Centeno, J., López, J., Lezama, L., Varela, G., et al. (2013) Innovations in plant health services in Nicaragua: from grassroots experiment to a systems approach. Journal of International Development 25(7), 968-986. https://doi.org/10.1002/jid.1786

Gêmo, H.R., Stevens, J.B. and Chilonda, P. (2013) The role of a pluralistic extension system in enhancing agriculture productivity in Mozambique. South African Journal of Agricultural Extension 41, 51-75. http://www. scielo.org.za/scielo. php?script=sci arttext\&pid=S0301$\underline{603 \times 2013000100006}$ (Accessed 19 April 2021)

Ghosh, S., Taron, A. and Williams, F. (2019) The impact of plant clinics on the livelihoods of Bangladeshi farmers. CABI Study Brief 29: Impact. https://dx.doi.org/10.1079/CABICOMM$\underline{62-8107}$

Gurmessa, N.E. and Bundi, M. (2021) Use of plant clinic advice among farmers in Ethiopia: implications for sustainable pest management service. International Journal of Pest Management, early-view. https://doi.org/10.1080/09670874.2020.1869348 
IFDC (International Fertilizer Development Center) (2015) Assessment of Fertilizer Consumption and Use by Crop in Ethiopia. IFDC, Addis Ababa 20 pp. Available at: https://africafertilizer.org/wp-content/uploads/2017/05/FUBC-Ethiopia-Final-Report-2016.pdf (accessed 24 May 2021).

Klerkx, L., Landini, F. and Santoyo-Cortés, H. (2016) Agricultural extension in Latin America: current dynamics of pluralistic advisory systems in heterogeneous contexts. The Journal of Agricultural Education and Extension 22(5), 389-397.

https://doi.org/10.1080/1389224X.2016.1227044

Masangano, C.M., Kambewa, D., Bosscher, N. and Fatch, P. (2017) Malawi's experiences with the implementation of pluralistic, demand-driven and decentralised agricultural extension policy. Journal of Agricultural Extension and Rural Development 9(9), 185-195. https://doi.org/10.5897/JAERD2017.0875

MoANR (Ministry of Agriculture and Natural Resources) (2016) Pest Management Support Services Strategy for Ethiopia. MoANR, Addis Ababa, Ethiopia, 51 pp. Available at: http://publication.eiar.gov.et:8080/xmlui/handle/123456789/2549 (accessed 24 May 2021).

Musebe, R., Bundi, M., Mugambi, I., Akundabweni, S., Nambiro, E. and Chege, F. (2018) Effects of plant clinics on pesticides usage by farming households in Kenya. Journal of Economics and Sustainable Development 9(12), 36-45. Available at: https://iiste.org/Journals/index.php/JEDS/article/view/43139 (accessed 24 May 2021).

Negatu, B., Kromhout, H., Mekonnen, Y. and Vermeulen. R. (2016) Use of chemical pesticides in Ethiopia: a cross-sectional comparative study on knowledge, attitude and practice of farmers and farm workers in three farming systems. The Annals of Occupational Hygiene 60(5), 551-566. https://doi.org/10.1093/annhyg/mew004

Negussie, E., Konjit, F., Crozier, J., Solomon, M. and Zebdewos, S. (2017) Bridging the gaps in plant health advisory services through community-based plant clinics: lessons and prospects. Pest Management Journal of Ethiopia 20, 1-14.

Ragasa, C., Berhane, G., Tadesse, F. and Seyoum, A. (2013) Gender differences in access to extension services and agricultural productivity. The Journal of Agricultural Education and Extension 19(5), 437-468. https://doi.org/10.1080/1389224X.2013.817343

Savary, S., Willocquet, L., Pethybridge, S.J., Esker, P., McRoberts, N. and Nelson, A. (2019) The global burden of pathogens and pests on major food crops. Nature Ecology \& Evolution 3(3), 430-439. https://doi.org/10.1038/s41559-018-0793-y

Shiferaw, A., Dindamo, B., Lemma, T. and Hoekstra, D. (2016) Agricultural service delivery: strengthening private crop protection service in southern Ethiopia. Development in Practice 26(8), 1072-1082. https://doi.org/10.1080/09614524.2016.1225670

Silvestri, S., Macharia, M. and Uzayisenga, B. (2019) Analysing the potential of plant clinics to boost crop protection in Rwanda through adoption of IPM: the case of maize and maize stem borers. Food Security 11, 301-305. https://doi.org/10.1007/s12571-019-00910-5

Singh, K.M., Swanson, B. and Meena, M. (2013) Reforming India's Pluralistic Extension System: Some Policy Issues. Available at SSRN: https://ssrn.com/abstract=2306980 or http://dx.doi.org/10.2139/ssrn.2306980 (accessed 24 May 2021). 
Tambo, J., Uzayisenga, B., Mugambi, I., Bundi, M. and Silvestri, S. (2020) Plant clinics, farm performance and poverty alleviation: panel data evidence from Rwanda. World Development 129, 104881. https://doi.org/10.1016/j.worlddev.2020.104881

Tambo, J.A., Romney, D., Mugambi, I., Mbugua, F., Bundi, M., et al. (2021) Can plant clinics enhance judicious use of pesticides? Evidence from Rwanda and Zambia. Food Policy, in press. https://doi.org/10.1016/j.foodpol.2021.102073 


\section{contact CABI}

\section{Africa}

Kenya

CABI, Canary Bird

673 Limuru Road, Muthaiga

PO Box 633-00621

Nairobi, Kenya

T: +254 (0)20 2271000/ 20

E: africa@cabi.org

\section{Ghana}

CABI, CSIR Campus

No. 6 Agostino Neto Road

Airport Residential Area

P. O. Box CT 8630, Cantonments

Accra, Ghana

T: +233 (0)302 797202

E: westafrica@cabi.org

Zambia

CABI, Southern Africa Centre

5834 Mwange Close

Kalundu

P.O. Box 37589

Lusaka, Zambia

T: +260967619665

E: westafrica@cabi.org

\section{Americas}

Brazil

CABI, UNESP-Fazenda Experimental Lageado, FEPAF (Escritorio da CABI)

Rua Dr. Jose Barbosa de Barros 1780

Fazenda Experimental Lageado

CEP:18.610-307

Botucatu, São Paulo, Brazil

T: +5514-38826300

E: y.colmenarez@cabi.org

Trinidad \& Tobago

CABI, Gordon Street, Curepe

Trinidad and Tobago

T: +18686457628

E: caribbeanLA@cabi.org

USA

CABI, 745 Atlantic Avenue

8th Floor, Boston,

MA 02111, USA

T: +1 (617) 682-9015

E: cabi-nao@cabi.org

\section{Asia}

China

CABI, Beijing Representative Office

Internal Post Box 85

Chinese Academy of Agricultural Sciences

12 Zhongguancun Nandajie

Beijing 100081, China

T: +86 (0)10 82105692

E: china@cabi.org

\section{India}

CABI, 2nd Floor, CG Block,

NASC Complex, DP Shastri Marg

Opp. Todapur Village, PUSA

New Delhi - 110012, India

T: +91 (0)1125841906

E: cabi-india@cabi.org

Malaysia

CABI, PO Box 210,

43400 UPM Serdang

Selangor, Malaysia

T: +60 (0)3 89432921

E: cabisea@cabi.org

Pakistan

CABI, Opposite 1-A,

Data Gunj Baksh Road

Satellite Town, PO Box 8

Rawalpindi, Pakistan

T: +92 (0)519290132

E: sasia@cabi.org

\section{Europe}

Switzerland

CABI, Rue des Grillons 1

$\mathrm{CH}-2800$ Delémont, Switzerland

T: + 41 (0)32 4214870

E: europe-CH@cabi.org

UK

CABI, Nosworthy Way

Wallingford, Oxfordshire, OX10 8DE, UK T: +44 (0)1491832111

E: corporate@cabi.org

CABI, Bakeham Lane

Egham, Surrey, TW20 9TY, UK

T: + 44 (0)1491 829080

E: cabieurope-uk@cabi.org

E:microbialservices@cabi.org 